\title{
REGULASI TEKNOLOGI FINANSIAL (FINTECH) DI INDONESIA
}

\section{REGULATION OF FINANCIAL TECHNOLOGY (FINTECH) IN INDONESIA}

\author{
Baginda Persaulian \\ Institut Agama Islam Negeri (IAIN) Bukittinggi \\ bagindaparsaulian@yahoo.com
}

Abstrak: $\quad$ Regulasi Teknologi Finansial (Fintech) Di Indonesia dengan tujuan untuk memastikan Keberadaan perusahaan penyelenggara teknologi financial (Fintech). Metode penelitian yang digunakan adalah dengan pendekatan Literature review yang memuat uraian mengenai teori, temuan dan bahan lainnya yang diperoleh dari bahan acuan untuk dijadikan landasan kegiatan penelitian untuk menyusun kerangka pemikiran dalam penelitian ini. Hasil penelitian ini menunjukan bahwa Keberadaan perusahaan penyelenggara teknologi financial (Fintech) menyebabkan masyarakat kebingungan dalam memilih perusahaan yang sesuai dengan kebutuhannya. Salah satu pertimbangan yang paling utama yang harus diperhatikan oleh masyarakat adalah sisi legalitas. Pemahaman masyarakat tersebut diakibatkan oleh pengetahuan masyarakat mengenai teknologi financial (Fintech), literature serta sosialiasi yang membahas mengenai regulasi Teknologi financial (Fintech) serta sosialisasi terutama mengenai regulasi masih terbatas. Oleh karena itu, tujuan dari tulisan ini adalah memberikan gambaran serta pemahaman mengenai regulasi teknologi financial (Fintech) di Indonesia.

Kata Kunci: Regulasi; Teknologi Finansial; Indonesia

Abstract: $\quad$ Regulation of Financial Technology (Fintech) in Indonesia with the aim of ensuring the existence of companies providing financial technology (Fintech). The research method used is a 
Literature review approach which contains a description of the theory, findings and other materials obtained from reference materials to be used as the basis for research activities to develop a framework of thought in this research. The results of this study indicate that the existence of financial technology (Fintech) companies causes people to be confused in choosing a company that suits their needs. One of the most important considerations that must be considered by the community is the legal side. This public understanding is caused by public knowledge about financial technology (Fintech), literature and socialization that discusses financial technology (Fintech) regulations and socialization, especially regarding regulations, is still limited. Therefore, the purpose of this paper is to provide an overview and understanding of financial technology (Fintech) regulations in Indonesia.

Keywords: Regulation; Financial Technology; Indonesia

\section{PENDAHULUAN}

Seluruh aspek dalam kehidupan modern saat ini tidak terlepas dan ditopang sepenuhnya oleh uang. Tidak ada satu peradaban didunia ini yang tidak mengenal dan menggunakan uang. Kalaupun ada, maka perekonomian dalam peradaban tersebut pasti stanan dan tidak berkembang. ${ }^{1}$ Teknologi financial (Fintech) muncul dan berkembang seiring perubahan gaya hidup masyarakat dengan dominasi tehnologi dalam kehidupan sehari-hari dengan pengguna teknologi informasi dikarenakan tuntutan hidup yang serba cepat dan praktis.

Dengan Teknologi financial (Fintech), berbagai permasalahan dalam transaksi jual-beli dan transaksi pembayaran seperti tidak sempat mencari barang ke tempat pasar/pusat perbelanjaan, keterbatasan waktu ke bank/ATM untuk mentransfer dana, pelayanan yang kurang menyenangkan serta berbagai kendalam lainnya yang merupakan hambatan dapat diminimalkan. Dengan kata lain, Teknologi financial (Fintech) membantu transaksi jual beli dan sistem pembayaran menjadi lebih efisien dan ekonomis namun tetap efektif.

1. Rimsky. K.Judisseno, 2005, Sistem Moneter dan Perbankan di Indonesia, Jakarta : PT. Gramedia Pustaka Utama. Hal. 1 
Teknologi Finansial (Fintech) telah merubah sistem keuangan menjadi lebih mudah dan cepat dimana dalam proses transaksi tidak lagi menggunakan uang secara fisik (uang kartal) dan giro (uang giral) maupun rekening di perbankan tetapi sejumlah dana yang telah ditransfer dan diakui sebagai saldo pada aplikasi tertentu dan dapat digunakan untuk melakukan transaksi keuangan sama seperti menggunakan uang fisik (uang kartal) tetapi lebih mudah dan praktis dengan menggunakan telepon seluler dan aplikasi tersebut. Cashless merupakan kegiatan bertransaksi tanpa harus menggunakan uang tunai, melainkan menggunakan electronic money dan beragam kartu, sedangkan cardless adalah transaksi tanpa penggunaan kartu sama sekali.

Dengan kemajuan tehnologi hanya dengan smartphone yang dilengkapi dengan aplikasi digital payment, transaksi keuangan sudah dapat dilakukan. Digital payment atau yang biasa dikenal sebagai $e$ payment merupakan sistem pembayaran elektronik melalui platform online yang dilakukan secara real time. Dengan metode digital payment ini, tidak diperlukan lagi keberdaan uang tunai dalam transaksi keuangan sehari-hari.

Debut kehadiran perusahaan teknologi keuangan ini diawali dengan kemunculan Zopa pada 2004, yakni sebuah institusi keuangan di Inggris yang menawarkan layanan jasa peminjaman uang. Sementara di Indonesia, teknologi financial (Fintech) dikenal dan mulai booming pada tahun 2016 dan bisnis ini sampai saat ini terus berkembang tanpa henti. Startup teknologi financial (Fintech) di Indonesia semakin bertambah baik dari segi jumlah dan jenis layanan yang semakin kompetitif. Dari sisi pendanaan bisnis, saat ini sudah banyak perusahaan venture capital dan accelerator yang melirik industri FinTech di Indonesia.

Teknologi financial (Fintech) merupakan salah satu bentuk penerapan teknologi informasi di bidang keuangan. Sementara pengertian fintech dari Bank Indonesia (BI) adalah hasil gabungan antara jasa keuangan dan teknologi yang akhirnya mengubah model bisnis dari konvensional menjadi moderat. Semua layanan keuangan berbasis digital berada di bawah pengawasan Bank Indonesia dan OJK. Bank Indonesia dan OJK saling bekerja sama dalam mengawasi perkembangan Teknologi financial (Fintech) di Indonesia.

Oleh karena itu, perusahaan Teknologi financial (Fintech) yang beroperasi di Indonesia wajib mematuhi regulasi yang telah ditetapkan 
denga melaporkan perusahaan mereka ke kedua institusi ini. Perusahaan Teknologi financial (Fintech) dalam operasionalnya akan mengumpulkan informasi data konsumen dan menjalankan bisnisnya dalam bidang keuangan sehingga apabila tidak diawasi maka akan merugikan masyarakat. Kuatnya arus teknologi dalam system pembayaran mendorong Bank Indonesia sebagai bank sentral Republik Indonesia untuk memastikan lalu lintas pembayaran yang telah terpenetrasi oleh teknologi tetap berjalan dengan tertib dan aman serta mendukung pilar-pilar dalam pencapaian visi dan misi Bank Indonesia.

Menjamurnya keberadaan perusahaan penyelenggara teknologi financial (Fintech) di sisi lain menyebabkan masyarakat kebingungan dalam memilih perusahaan yang sesuai dengan kebutuhannya. Salah satu pertimbangan yang paling utama yang harus diperhatikan oleh masyarakat adalah sisi legalitas. Pemahaman masyarakat tersebut diakibatkan oleh pengetahuan masyarakat mengenai teknologi financial (Fintech), literature serta sosialiasi yang membahas mengenai regulasi Teknologi financial (Fintech) serta sosialisasi terutama mengenai regulasi masih terbatas. Oleh karena itu, tujuan dari tulisan ini adalah memberikan gambaran serta pemahaman mengenai regulasi teknologi financial (Fintech) di Indonesia.

\section{METODE}

Metode yang digunakan dalam tulisan ini adalah literature review. Literature review memuat uraian mengenai teori, temuan dan bahan lainnya yang diperoleh dari bahan acuan untuk dijadikan landasan kegiatan penelitian untuk menyusun kerangka pemikiran yang jelas dari perumusan masalah yang ingin diteliti/diketahui.

\section{HASIL DAN PEMBAHASAN}

\section{Hasil Penelitian}

\section{Ruang Lingkup Operasional Bisnis Teknologi Finansial (Fintech)}

Teknologi Finansial (Fintech) adalah penggunaan teknologi dalam sistem keuangan yang menghasilkan produk, layanan, teknologi, dan/atau model bisnis baru serta dapat berdampak pada stabilitas moneter, stabilitas sistem keuangan, dan/atau efisiensi, kelancaran, keamanan, dan keandalan sistem pembayaran. Penyelenggara Teknologi Finansial adalah setiap pihak yang menyelenggarakan 
kegiatan Teknologi Finansial sedangkan penyelenggara Jasa Sistem Pembayaran adalah penyelenggara jasa sistem pembayaran sebagaimana dimaksud dalam ketentuan Bank Indonesia yang mengatur mengenai penyelenggaraan pemrosesan transaksi pembayaran. ${ }^{2}$

Bank Indonesia telah mengklasifikasikan teknologi financial (Fintech) ke dalam 4 (empat) kelompok, yakni:

1) Pembayaran, Setelmen, dan Kliring, merupakan kategori fintech yang memberi layanan sistem pembayaran yang dilakukan bank maupun $\mathrm{BI}$;

2) Market Aggregator, merupakan fintech yang menyajikan data finansial sehingga dapat dipakai pengguna sebagai perbandingan untuk memilih produk keuangan yang tepat;

3) Manajemen Risiko dan Investasi, merupakan fintech yang berfungsi seperti layaknya perencana keuangan bagi pengguna. sehingga fintech ini berfungsi untuk membantu penggunanya dalam memilih produk keuangan yang cocok ssuai dengan kebutuhan pengguna;

4) Peer to Peer Lending ( $P 2 P$ Lending) adalah fintech yang menawarkan pinjaman langsung kepada pengguna dengan bunga yang telah ditetapkan.

Teknologi financial (Fintech) mampu menggantikan peran lembaga keuangan formal seperti bank. Dalam hal sistem pembayaran, peran teknologi financial (Fintech) adalah:

1) Menyediakan pasar bagi pelaku usaha;

2) Menjadi alat bantu untuk pembayaran, penyelesaian/settlement dan kliring;

3) Membantu pelaksanaan investasi yang lebih efisien

4) Mitigasi risiko dari system pembayaran yang konvensional;

5) Membantu pihak yang membutuhkan untuk menabung, meminjam dana dan penyertaan modal.

Bank Indonesia berpern dalam dalam menjaga ketertiban lalu lintas pembayaran terkait FinTech yaitu : dalam hal penyediaan pasar bagi pelaku usaha, Bank Indonesia memastikan perlindungan terhadap konsumen, khususnya mengenai jaminan kerahasiaan data dan informasi konsumen lewat jaringan keamanan siber; dalam hal

2 Peraturan Bank Indonesia No.19/12/PBI/2017 Tentang Penyelenggaraan Teknologi Finansial 
tabungan, pinjaman dan penyertaan modal, Bank Indonesia mewajibkan setiap pelaku usaha untuk patuh kepada peraturan makroprudensial, pendalaman mengenai pasar keuangan, system pembayaran sebagai pendukung operasi dan keamanan siber untuk menjaga data dan informasi konsumen; dalam hal investasi dan manajemen risiko, Bank Indonesia juga mewajibkan setiap pelaku usaha untuk patuh kepada peraturan makroprudensial, pendalaman mengenai pasar keuangan, system pembayaran sebagai pendukung operasi dan keamanan siber untuk menjaga data dan informasi konsumen; dalam hal pembayaran, penyelesaian/settlement dan kliring, Bank Indonesia memastikan perlindungan terhadap konsumen, khususnya mengenai jaminan kerahasiaan data dan informasi konsumen lewat jaringan keamanan siber.

2. Regulasi Operasional Bisnis Teknologi Finansial

a Peraturan Otoritas Jasa Keuangan (POJK) Nomor 77/POJK.01/2016 tentang Layanan Pinjam Meminjam Uang Berbasis Teknologi Informasi (LPMUBTI)

OJK membuat aturan ini untuk mengatur berbagai hal yang harus ditaati oleh penyelenggara bisnis pinjaman dari pengguna ke pengguna, atau yang biasa disebut dengan fintech peer to peer lending (P2P lending). Pada intinya, POJK Nomor 77/POJK.01/2016 bertujuan untuk melindungi konsumen terkait keamanan dana dan data, pencegahan pencucian uang dan pendanaan terorisme, stabilitas sistem keuangan, hingga para pengelola perusahaan fintech. Ketentuan ini mengatur mengenai batasan kepemilikan saham, modal minimal, batas maksimal pinjaman dan bunga, keharusan pembuatan escrow account, serta beberapa prinsip yang wajib diterapkan penyelenggara fintech.

b Peraturan Bank Indonesia (PBI) Nomor 18/40/PBI/2016 tentang Penyelenggaraan Pemrosesan Transaksi Pembayaran (PTP)

Terbitnya PBI Nomor 18/40/PBI/2016 ini bertujuan untuk memenuhi kebutuhan masyarakat, termasuk di bidang jasa sistem pembayaran, baik dari sisi instrumen, penyelenggara, mekanisme maupun infrastruktur penyelenggaraan pemrosesan transaksi pembayaran. Cakupan dalam PBI Nomor 18/40/PBI/2016 ini meliputi penyelenggara dalam pemrosesan transaksi pembayaran, perizinan dan persetujuan dalam penyelenggaraan pemrosesan transaksi 
pembayaran, kewajiban dalam penyelenggaraan pemrosesan transaksi pembayaran, laporan, peralihan izin penyelenggara jasa sistem pembayaran dan pengawasan, larangan, serta sanksi.

c Peraturan Bank Indonesia (PBI) Nomor 19/12/PBI/2017 Tentang Penyelenggaraan Teknologi Finansial

Perkembangan fintech di Indonesia tumbuh begitu cepat sehingga dikhawatirkan akan berdampak buruk pada penyelenggaraannya. Untuk itu, BI menerbitkan PBI Nomor 19/12/PBI/2017 sebagai payung hukum demi menjaga kestabilan sistem keuangan di Indonesia tersebut. Terbitnya PBI Nomor 19/12/PBI/2017 ini bertujuan untuk mendukung terciptanya stabilitas moneter, stabilitas sistem keuangan, serta sistem pembayaran yang efisien, lancar, aman, dan andal untuk mendukung pertumbuhan ekonomi nasional yang berkelanjutan dan inklusif dengan menerapkan prinsip perlindungan konsumen serta manajemen risiko dan kehati-hatian.

Di samping itu, BI juga menerbitkan ketentuan pelaksanaan PBI Penyelenggaraan Teknologi Finansial diatur dalam Peraturan Anggota Dewan Gubernur (PADG) No. 19/14/PADG/2017 tentang Ruang Uji Coba Terbatas (Regulatory Sandbox) Teknologi Finansial dan PADG No. 19/15/PADG/2017 tentang Tata Cara Pendaftaran, Penyampaian Informasi, dan Pemantauan Penyelenggara Teknologi Finansial. Bank Indonesia mengatur penyelenggaraan Teknologi Finansial untuk mendorong inovasi di bidang keuangan dengan menerapkan prinsip perlindungan konsumen serta manajemen risiko dan kehati-hatian guna tetap menjaga stabilitas moneter, stabilitas sistem keuangan, dan sistem pembayaran yang efisien, lancar, aman, dan andal.

Pertimbangan yang dilihat oleh Bank Indonesia sehingga diterbitkannya PBI No.19/12/PBI/2017 tanggal 29 November 2017 tentang Penyelenggaraan Teknologi Finansial oleh Bank Indonesia adalah sebagai berikut:

1) Perkembangan teknologi dan sistem informasi terus melahirkan berbagai inovasi, khususnya yang berkaitan dengan teknologi finansial untuk memenuhi berbagai kebutuhan masyarakat termasuk akses terhadap layanan finansial dan pemrosesan transaksi; 
2) Perkembangan teknologi finansial di satu sisi terbukti membawa manfaat bagi konsumen, pelaku usaha maupun perekonomian nasional, namun di sisi lain memiliki potensi risiko yang apabila tidak dimitigasi secara baik dapat mengganggu sistem keuangan;

3) Ekosistem teknologi finansial perlu terus dimonitor dan dikembangkan untuk mendukung terciptanya stabilitas moneter, stabilitas sistem keuangan, serta sistem pembayaran yang efisien, lancar, aman, dan andal untuk mendukung pertumbuhan ekonomi nasional yang berkelanjutan dan inklusif;

4) Penyelenggaraan teknologi finansial harus menerapkan prinsip perlindungan konsumen serta manajemen risiko dan kehatihatian dengan tetap memperhatikan perluasan akses, kepentingan nasional, serta standar dan praktik internasional yang berlaku;

5) Respons kebijakan Bank Indonesia terhadap perkembangan teknologi finansial harus tetap sinkron, harmonis, dan terintegrasi dengan kebijakan Bank Indonesia lainnya seperti penyelenggaraan pemrosesan transaksi pembayaran dan gerbang pembayaran nasional (national payment gateway) serta perlu dikoordinasikan dengan otoritas.

Perkembangan teknologi finansial di satu sisi terbukti membawa manfaat bagi konsumen, pelaku usaha, maupun perekonomian nasional, namun di sisi lain memiliki potensi risiko yang apabila tidak dimitigasi secara baik dapat mengganggu sistem keuangan. Teknologi Finansial (Fintech) telah merubah sistem keuangan menjadi modern dimana dalam proses transaksi tidak lagi menggunakan uang secara fisik (uang kartal) dan giro (uang giral) serta rekening di perbankan tetapi sejumlah dana yang telah ditransfer dan diakui sebagai saldo. Regulasi yang mengatur yang ada saat ini adalah:

1) Undang-Undang Nomor 23 Tahun 1999 tentang Bank Indonesia (Lembaran Negara Republik Indonesia Tahun 1999 Nomor 66, Tambahan Lembaran Negara Republik Indonesia Nomor 3843) sebagaimana telah beberapa kali diubah, terakhir dengan Undang-Undang Nomor 6 Tahun 2009 tentang Penetapan Peraturan Pemerintah Pengganti Undang-Undang Nomor 2 
Tahun 2008 tentang Perubahan Kedua atas Undang-Undang Nomor 23 Tahun 1999 tentang Bank Indonesia menjadi UndangUndang (Lembaran Negara Republik Indonesia Tahun 2009 Nomor 7, Tambahan Lembaran Negara Republik Indonesia Nomor 4962);

2) Undang-Undang Nomor 11 Tahun 2008 tentang Informasi dan Transaksi Elektronik (Lembaran Negara Republik Indonesia Tahun 2008 Nomor 58, Tambahan Lembaran Negara Republik Indonesia Nomor 4843) sebagaimana telah diubah dengan Undang-Undang Nomor 19 Tahun 2016 tentang Perubahan atas Undang-Undang Nomor 11 Tahun 2008 tentang Informasi dan Transaksi Elektronik (Lembaran Negara Republik Indonesia Tahun 2016 Nomor 251, Tambahan Lembaran Negara Republik Indonesia Nomor 5952).

3) Undang-Undang Nomor 3 Tahun 2011 tentang Transfer Dana (Lembaran Negara Republik Indonesia Tahun 2011 Nomor 39, Tambahan Lembaran Negara Republik Indonesia Nomor 5204).

4) Undang-Undang Nomor 7 Tahun 2011 tentang Mata Uang (Lembaran Negara Republik Indonesia Tahun 2011 Nomor 64, Tambahan Lembaran Negara Republik Indonesia Nomor 5223).

Sehubungan dengan hal tersebut di atas, serta untuk mendorong inovasi di bidang keuangan dengan menerapkan prinsip perlindungan konsumen serta manajemen risiko dan kehati-hatian guna tetap menjaga stabilitas moneter, stabilitas sistem keuangan, dan sistem pembayaran yang efisien, lancar, aman, dan andal, Bank Indonesia sebagai otoritas sistem pembayaran telah menerbitkan Peraturan Bank Indonesia (PBI) dan Peraturan Anggota Dewan Gubernur (PADG) mengenai Teknologi Finansial dan Regulatory Sandbox. Melalui PBI No.19/12/PBI/2017 tentang Penyelenggaraan Teknologi Finansial, Bank Indonesia mengatur mengenai kewajiban pendaftaran di Bank Indonesia bagi Penyelenggara Teknologi Finansial yang melakukan kegiatan sistem pembayaran. Kewajiban pendaftaran tersebut dikecualikan bagi Penyelenggara Jasa Sistem Pembayaran yang telah memperoleh izin dari Bank Indonesia dan bagi Penyelenggara Teknologi Finansial yang berada dibawah kewenangan otoritas lain. 


\section{Pembahasan}

Teknologi financial (Fintech) muncul dan berkembang seiring perubahan gaya hidup masyarakat dengan dominasi tehnologi dalam kehidupan sehari-hari dengan pengguna teknologi informasi dikarenakan tuntutan hidup yang serba cepat dan praktis. Dengan Teknologi financial (Fintech), berbagai permasalahan dalam transaksi jual-beli dan transaksi pembayaran seperti tidak sempat mencari barang ke tempat pasar/pusat perbelanjaan, keterbatasan waktu ke bank/ATM untuk mentransfer dana, pelayanan yang kurang menyenangkan serta berbagai kendalam lainnya yang merupakan hambatan dapat diminimalkan. Dengan kata lain, Teknologi financial (Fintech) membantu transaksi jual beli dan sistem pembayaran menjadi lebih efisien dan ekonomis namun tetap efektif.

Teknologi Finansial (Fintech) telah merubah sistem keuangan menjadi lebih mudah dan cepat dimana dalam proses transaksi tidak lagi menggunakan uang secara fisik (uang kartal) dan giro (uang giral) maupun rekening di perbankan tetapi sejumlah dana yang telah ditransfer dan diakui sebagai saldo pada aplikasi tertentu dan dapat digunakan untuk melakukan transaksi keuangan sama seperti menggunakan uang fisik (uang kartal) tetapi lebih mudah dan praktis dengan menggunakan telepon seluler dan aplikasi tersebut.

Bank Indonesia berpern dalam dalam menjaga ketertiban lalu lintas pembayaran terkait FinTech yaitu : dalam hal penyediaan pasar bagi pelaku usaha, Bank Indonesia memastikan perlindungan terhadap konsumen, khususnya mengenai jaminan kerahasiaan data dan informasi konsumen lewat jaringan keamanan siber; dalam hal tabungan, pinjaman dan penyertaan modal, Bank Indonesia mewajibkan setiap pelaku usaha untuk patuh kepada peraturan makroprudensial, pendalaman mengenai pasar keuangan, system pembayaran sebagai pendukung operasi dan keamanan siber untuk menjaga data dan informasi konsumen; dalam hal investasi dan manajemen risiko, Bank Indonesia juga mewajibkan setiap pelaku usaha untuk patuh kepada peraturan makroprudensial, pendalaman mengenai pasar keuangan, system pembayaran sebagai pendukung operasi dan keamanan siber untuk menjaga data dan informasi konsumen; dalam hal pembayaran, penyelesaian/settlement dan kliring, Bank Indonesia memastikan perlindungan terhadap konsumen, khususnya mengenai jaminan kerahasiaan data dan informasi konsumen lewat jaringan keamanan siber. 


\section{PENUTUP}

Kehadiran fintech bermanfaat bagi berbagai pihak baik masyarakat, perusahaan dan institusi keuangan dan negara. Bagi masyarakat, manfaat yang dapat diperoleh diantaranya adalah pengguna jasa keuangan dapat menikmati layanan yang lebih baik dan cepat, pilihan produk dan fitur yang lebih beragam mengurangi frekuensi kunjungan ke kantor layanan keuangan sehingga dapt menghemat waktu. Selain itu, konsumen pun mengeluarkan biayna lebih murah. Bagi perusahaan maupun institusi keuangan, manfaat yang dapat diperoleh diantaranya peyederhanakan dalam proses transaksi keuangan. Perusahaan maupun institusi keuangan dapat menekan biaya operasional dan biaya modal. Bagi negara, manfaat yang dapat diperoleh dari layanan teknologi financial (Fintech) ini pun berdampak positif. Dengan adanya fintech, perputaran uang dalam kegiatan perekonomian menjadi lebih cepat sehingga dapat meningkatkan kesejahteraan ekonomi masyarakat secara luas. teknologi financial (Fintech) berperan mendorong dalam transmisi kebijakan ekonomi serta turut serta dalam program pemerintah dalam mensosialisasikan keuangan inklusif yaitu Strategi Nasional Keuangan Inklusif (SKNI). 


\section{DAFTAR PUSTAKA}

Rimsky. K.Judisseno. 2005. Sistem Moneter dan Perbankan di Indonesia. Jakarta : PT. Gramedia Pustaka Utama.

Undang-Undang Nomor 6 Tahun 2009 tentang Penetapan Peraturan Pemerintah Pengganti Undang-Undang Nomor 2 Tahun 2008 tentang Perubahan Kedua atas Undang-Undang Nomor 23 Tahun 1999 tentang Bank Indonesia menjadi Undang-Undang

Undang-Undang Nomor 19 Tahun 2016 tentang Perubahan atas UndangUndang Nomor 11 Tahun 2008 tentang Informasi dan Transaksi Elektronik

Undang-Undang Nomor 3 Tahun 2011 tentang Transfer Dana Undang-Undang Nomor 7 Tahun 2011 tentang Mata Uang

PBI No.19/12/PBI/2017 tanggal 29 November 2017 tentang Penyelenggaraan Teknologi Finansial

PADG No.19/15/PADG/2017 tentang Tata Cara Pendaftaran, Penyampaian Informasi dan Pemantauan Penyelenggaraan Teknologi Finansial.

Surat Edaran BI No. 18/22/DKSP Tentang Penyelenggaraan Layanan Keuangan Digital Peraturan BI No. 18/17/PBI/2016 tentang Uang Elektronik

Peraturan Otoritas Jasa Keuangan (POJK) Nomor 77/POJK.01/2016 tentang Layanan Pinjam Meminjam Uang Berbasis Teknologi Informasi (LPMUBTI)

Peraturan Bank Indonesia (PBI) Nomor 18/40/PBI/2016 tentang Penyelenggaraan Pemrosesan Transaksi Pembayaran (PTP). 